\title{
PHYTOCHEMICAL AND PHARMACOLOGICAL EVALUATION OF COMMIPHORA MUKUL FOR ANTIDEPRESSANT ACTIVITY IN ALBINO MICE
}

\author{
VIJETHA PENDYALA*, RAMESH BABU JANGA, VIDYADHARA SURYADEVARA
}

Department of Pharmacognosy, Chebrolu Hanumaiah Institute of Pharmaceutical Sciences, Guntur, Andhra Pradesh, India. Email: vijetha.85@gmail.com

Received: 24 September 2016, Revised and Accepted: 15 October 2016

\section{ABSTRACT}

Objective: The main aim and objective of the present study is to investigate the effect of Commiphora mukul (Family: Burseraceae), on depression in mice using tail suspension test (TST) and forced swim test (FST).

Methods: The oleo-gum resin of guggul was extracted with alcohol and fractionated with ethyl acetate and petroleum ether. All the fractions were subjected for preliminary phytochemical screening, using various qualitative tests. Till date, no scientific data were available on the antidepressant activity of this plant. So, in the present investigation, TST and FST are selected as animal models for evaluation of antidepressant activity in albino mice.

Results: The preliminary phytochemical screening of guggul has revealed the presence of carbohydrates, proteins, tannins, and flavonoids in hydroalcoholic fraction. Ethyl acetate fraction showed positive results toward flavonoids, alkaloids, proteins, and steroids. Hydroalcoholic, ethyl acetate, and petroleum ether fractions (50 and $100 \mathrm{mg} / \mathrm{kg}$ p.o.) of guggul administered orally for 14 successive days had decreased the immobility periods significantly in a dose-dependent manner in both TST and FST, showing significant antidepressant-like activity. The activities of the fractions were found to be comparable to imipramine in both FST and TST.

Conclusions: Although a number of synthetic drugs are being used as standard treatment for clinically depressed patient, they have adverse effects that can compromise the therapeutic treatment. In the traditional systems of medicine, many plants and formulations have been used to treat depression for thousands of years. The results of this study indicate the potential for the use of guggul as an adjuvant in the treatment of depression.

Keywords: Guggul, Commiphora mukul, Antidepressant activity, Forced swim test, Tail suspension test, Depression.

(C) 2017 The Authors. Published by Innovare Academic Sciences Pvt Ltd. This is an open access article under the CC BY license (http://creativecommons. org/licenses/by/4. 0/) DOI: http://dx.doi.org/10.22159/ajpcr.2017.v10i1.15481

\section{INTRODUCTION}

Depression refers to a wide range of mental health problems characterized by the absence of positive effect (loss of interest and enjoyment in ordinary things and experiences), low mood and a range of associated emotional, cognitive, physical, and behavioral symptoms [1]. The prevalence rate for all mental disorders in India was observed to be $65.4 / 1000$ population, out of which, the prevalence rate for affective disorders is $31.2 / 1000$ population [2]. All the synthetic drugs available for the treatment of depression have various adverse effects and problematic interactions [3]; therefore, our aim was to explore the potential of plants in the treatment of depression.

Commiphora mukul (CM) (Burseraceae) is commonly known as Guggul, Indian bdellium-tree, gugal or mukul myrrh tree. It is a small shrub with maximum height of $4 \mathrm{mts}$. The branches are thorny; leaves are simple or trifoliate, leaflets are ovate $1-5 \mathrm{~cm}$ long, $0.5-2.5 \mathrm{~cm}$ broad [4]. In Ayurveda and Unani, the extract of this gum called guggulipid and it is used as a medicine for reducing obesity [5-7]. The oleo-gumresin is bitter, acrid astringent, aromatic, digestive, anthelmintic, antiinflammatory, antiseptic, stimulant, liver tonic, diuretic, rejuvenating general tonic, and useful in vitiated conditions of vata, scrofula, sciatica, facial paralysis, leprosy, leukoderma, cough, asthma, bronchitis, and hepatic disorders [8]. Chemical examination of guggul revealed the presence of complex structure made up of various compounds such as lignans, lipids, diterpenes, and steroids. The active constituents are Z-guggulsterone and E-3 guggulsterone [9,10]. Flowers contain D-glucuronide, ellagic acid, and pelargonidin; seed oil contains linoleic acid, palmitic acid, steric acid, campesterol, and cholesterol, stigmasterol [11]. Essential oil of guggul contains myrcene, dimyrcene, polymyrcene, and caryophylline [12].

The pharmacological activities reported for CM are anti-inflammatory, analgesic, antibacterial, and hypolipidemic activities. It is used in treatment of rheumatoid arthritis, skin diseases, piles, dental disorders [13]. The literature review reveals that no study was done on the antidepressant property of this plant scientifically. Therefore, our study was focused on evaluation of antidepressant potential of $\mathrm{CM}$ in mice. The present study was undertaken to investigate the effect of petroleum ether, ethyl acetate, and hydroalcoholic fractions of CM on depression in mice employing forced swim test (FST) and tail suspension test (TST).

\section{METHODS}

\section{Collection of plant material and fractionation}

Guggul, an oleo-gum-resin from the plant CM was procured from Yucca Enterprises, Mumbai. Guggul was grounded and then macerated with $50 \%$ alcohol and 50\% water for 14 days. Then, the extract was further evaporated using Simple distillation apparatus to get the concentrate. To this fraction aliquots of water was added and then fractionated successively using petroleum ether and ethyl acetate by mother liquor method [14]. To this extract $250 \mathrm{ml}$ of water was added and shaken thoroughly and then to this $100 \mathrm{ml}$ of petroleum ether was added to separate the nonpolar constituents. This procedure was repeated until the appearance of colorless petroleum ether layer. All the fractions of petroleum ether layer were collected and evaporated to a concentrated residue. After separation of petroleum ether fraction, $100 \mathrm{ml}$ of ethyl 
acetate was added to the hydroalcoholic extract, and this procedure is repeated until the ethyl acetate layer becomes colorless. All the fractions of chloroform layer were collected and evaporated to a concentrated residue. The leftover portion is considered as hydroalcoholic fraction.

\section{Preliminary phytochemical screening}

Various qualitative tests were performed for the detection of phytochemical constituents present in all three fractions, for the presence of carbohydrates, tannins, flavonoids, steroids, glycosides, alkaloids, saponins, etc., [15].

\section{Animals}

Swiss albino mice of either sex, 3-4 months old and weighing around 20-30 g, were selected. The animals had free access to food and water and were housed in an animal room with alternating light-dark cycle of $12 \mathrm{hrs}$ each. The animals were acclimatized for at least 5 days to the laboratory conditions before the commencement of behavioral experiments. Experiments were carried out between 9:00 am and 5:00 pm. The Institutional Animal Ethics Committee (IAEC) approved the experimental protocol, and the care of laboratory animals was taken as per the guidelines of CPCSEA, Ministry of Forests and Environment, Government of India (1529/PO/A/11/CPCSEA/IAEC3/ PRO-07/2014-2015).

\section{Preparation of standard}

Imipramine was procured from the Baroda Pharmaceuticals as gift sample. Stock solution was prepared by dissolving $10 \mathrm{mg}$ in $10 \mathrm{ml}$ of distilled water and then diluted to required dilutions.

\section{Measurement of antidepressant activity in albino mice}

In the present investigation, TST and FST were selected as animal models for the evaluation of antidepressant activity in albino mice

\section{Experimental protocol}

Animals were divided into 16 groups, and each group consists of 6 mice.

\section{Tail-suspension test}

The total duration of immobility induced by tail suspension was measured according to the method described by Steru et al. [16] and Thierry et al. [17]. Mice were suspended on the edge of a table $50 \mathrm{~cm}$ above the floor by the adhesive tape placed approximately $1 \mathrm{~cm}$ from the tip of the tail. Immobility time was recorded during a 6 minutes period. Animal was considered to be immobile when it did not show any movement of body and hanged passively. Each animal was used only once. The experimental protocol and treatment schedule were given in Table 1.

\section{FST}

FST was proposed as a model for antidepressant activity by Porsolt et al. $[18,19]$. Mice were forced to swim individually in a glass jar containing fresh water of $15 \mathrm{~cm}$ height and maintained at $25^{\circ} \mathrm{C}\left( \pm 3^{\circ} \mathrm{C}\right)$. A mice was considered to be immobile when it remained floating in the water without struggling, making no or minimum movements of its limbs necessary to keep its head above water. The total duration of immobility was recorded during a 6 minutes test. The changes in immobility duration were studied in all groups of animals. The experimental protocol and treatment schedule was given in Table 2. On $14^{\text {th }}$ day, at 90 minutes after administration of extracts, immobility period was recorded in all groups.

\section{Statistical analysis}

All the results were expressed as mean \pm standard error. Data were analyzed using one-way ANOVA followed by Dennett's test. In all the tests, the criterion for statistical significance was $\mathrm{p}<0.05$.

\section{RESULTS AND DISCUSSION}

Preliminary phytochemical screening was done for petroleum ether, ethyl acetate, and alcoholic extracts of CM using various qualitative tests. The results of phytochemical screening are presented in Table 3.

The results of different extracts of guggul on the immobility duration in TST are presented in Table 4. Administration of CM alcoholic (CMA), CM ethyl acetate (CME), and CM petroleum ether (CMP) $100 \mathrm{mg} / \mathrm{kg}$ for 14 successive days decreased the immobility time in TST by 58.8\%, 53.1\% and $15.7 \%$, respectively, as compared to control group. CMA, CME, and CMP $100 \mathrm{mg} / \mathrm{kg}$ administration for 14 days decreased immobility time in FST by $73.5 \%, 70.7 \%$ and $17.3 \%$, respectively, as compared to control group. Standard drug imipramine at a dose of $10 \mathrm{mg} / \mathrm{kg}, 14$ days treatment decreased the immobility time by $57.5 \%$ and $85.8 \%$, respectively, in TST and FST as compared to control group (Tables 4 and 5).

Table 1: Experimental protocol for TST

\begin{tabular}{lll}
\hline S. No. & Group & Treatment schedule for TST \\
\hline 1. & Control & Only distilled water was administered orally for 14 days \\
2. & Standard & Imipramine $(10 \mathrm{mg} / \mathrm{kg})$ was administered orally for 14 days \\
3. & CMA1 & Hydroalcoholic fraction of CM $(50 \mathrm{mg} / \mathrm{kg})$ was administered orally for 14 days \\
4. & CMA2 & Hydroalcoholic fraction of CM $(100 \mathrm{mg} / \mathrm{kg})$ was administered orally for 14 days \\
5. & CME1 & Ethyl acetate fraction of CM $(50 \mathrm{mg} / \mathrm{kg})$ was administered orally for 14 days \\
6. & CME2 & Ethyl acetate fraction of CM $(100 \mathrm{mg} / \mathrm{kg})$ was administered orally for 14 days \\
7. & CMP1 & Petroleum ether fraction of CM $(50 \mathrm{mg} / \mathrm{kg})$ was administered orally for 14 days \\
8. & CMP2 & Petroleum ether fraction of CM $(100 \mathrm{mg} / \mathrm{kg})$ was administered orally for 14 days \\
\hline
\end{tabular}

TST: Tail suspension test, CM: Commiphora mukul, CMA: Commiphora mukul with alcoholic, CME: Commiphora mukul with ethyl acetate, CMP: Commiphora mukul with petroleum ether

Table 2: Experimental protocol for FST

\begin{tabular}{lll}
\hline S. No. & Group & Treatment schedule for FST \\
\hline 1. & Control & Only distilled water was administered orally for 14 days \\
2. & Standard & Imipramine $(10 \mathrm{mg} / \mathrm{kg})$ was administered orally for 14 days \\
3. & CMA1 & Hydroalcoholic fraction of CM $(50 \mathrm{mg} / \mathrm{kg})$ was administered orally for 14 days \\
4. & CMA2 & Hydroalcoholic fraction of CM $(100 \mathrm{mg} / \mathrm{kg})$ was administered orally for 14 days \\
5. & CME1 & Ethyl acetate fraction of CM $(50 \mathrm{mg} / \mathrm{kg})$ was administered orally for 14 days \\
6. & CME2 & Ethyl acetate fraction of CM $(100 \mathrm{mg} / \mathrm{kg})$ was administered orally for 14 days \\
7. & CMP1 & Petroleum ether fraction of CM $(50 \mathrm{mg} / \mathrm{kg})$ was administered orally for 14 days \\
8. & CMP2 & Petroleum ether fraction of CM $(100 \mathrm{mg} / \mathrm{kg})$ was administered orally for 14 days \\
\hline
\end{tabular}

FST: Forced swim test, CM: Commiphora mukul, CMA: Commiphora mukul with alcoholic, CME: Commiphora mukul with ethyl acetate, CMP: Commiphora mukul with petroleum ether 
Table 3: Preliminary phytochemical analysis of fractions of guggul

\begin{tabular}{llll}
\hline Test for & CMP & CME & CMA \\
\hline Alkaloids & -ve & $+v e$ & $-v e$ \\
Flavonoids & -ve & $+v e$ & $-v e$ \\
Carbohydrates & $-v e$ & $-v e$ & $+v e$ \\
Proteins & $-v e$ & $+v e$ & $-v e$ \\
Tannins & $-v e$ & $-v e$ & $+v e$ \\
Steroids & $-v e$ & $+v e$ & $+v e$ \\
Fats and oils & + ve & -ve & -ve \\
\hline
\end{tabular}

CMA: Commiphora mukul with alcoholic, CME: Commiphora mukul with ethyl acetate, CMP: Commiphora mukul with petroleum ether

Table 4: Effect of guggul on immobility time in TST

\begin{tabular}{lll}
\hline Groups & $\begin{array}{l}\text { Mean+SEM of immobility } \\
\text { time (seconds) }\end{array}$ & $\begin{array}{l}\text { Percentage of decrease } \\
\text { in immobility time }\end{array}$ \\
\hline Control & $186.3 \pm 8.02$ & \\
Standard & $79.2 \pm 6.71^{* *}$ & 57.5 \\
CMA1 & $120.2 \pm 7.52^{*}$ & 35.5 \\
CMA2 & $76.6 \pm 4.02^{* *}$ & 58.8 \\
CME1 & $122.2 \pm 7.44^{*}$ & 33.5 \\
CME2 & $87.3 \pm 4.34^{* *}$ & 53.1 \\
CMP1 & $183 \pm 7.92$ & 2.2 \\
CMP2 & $157 \pm 6.52$ & 15.7 \\
\hline
\end{tabular}

Values are expressed as mean $\pm \mathrm{SEM},{ }^{*} \mathrm{p}<0.05,{ }^{* *} \mathrm{p}=0.01$, versus control group. TST: Tail suspension test, SEM: Standard error of the mean, CMA: Commiphora mukul with alcoholic, CME: Commiphora mukul with ethyl acetate,

CMP: Commiphora mukul with petroleum ether

Table 5: Effect of guggul on immobility time in FST

\begin{tabular}{lll}
\hline Groups & $\begin{array}{l}\text { Mean } \pm \text { SEM of immobility } \\
\text { time (seconds) }\end{array}$ & $\begin{array}{l}\text { Percentage of decrease } \\
\text { in immobility time }\end{array}$ \\
\hline Control & $87.6 \pm 5.2$ & \\
Standard & $12.5 \pm 2.17^{* * *}$ & 85.73 \\
CMA1 & $60.3 \pm 9.12^{*}$ & 31.2 \\
CMA2 & $23.16 \pm 4.93^{* *}$ & 73.5 \\
CME1 & $58.16 \pm 13.3^{*}$ & 33.6 \\
CME2 & $25.6 \pm 7.15^{* *}$ & 70.7 \\
CMP1 & $77.5 \pm 4.41$ & 11.5 \\
CMP2 & $72.4 \pm 4.64$ & 17.3 \\
\hline
\end{tabular}

Values are expressed as mean $\pm \mathrm{SEM},{ }^{*} \mathrm{p}<0.05,{ }^{* *} \mathrm{p}<0.01,{ }^{* * *} \mathrm{p}<0.001$, versus control group. FST: Forced swim test, SEM: Standard error of the mean, CMA: Commiphora mukul with alcoholic, CME: Commiphora mukul with ethyl acetate, CMP: Commiphora mukul with petroleum ether

The incidence of anxiety and depression in the community is very high and is associated with lot of morbidities. Hence, it is very important to address these problems and find effective remedies. Although several drugs are available, all are associated with some limitations, and there is an urgent need for alternative medications for these disorders [20]. Ayurveda mentions a number of single and compound drug formulations of plant origin that are used in the treatment of psychiatric disordersand are claimed to have a better acceptance than conventional drugs due to lower incidence of side effects [21]. Despite the widely popular use of guggul for treating nervous disorders, there is an absence of scientific reports about the evaluation of its pharmacological effects. In this work, it was demonstrated that the administration of different doses of the methanolic extract of guggul in mice was able to induce antidepressant effects. Various phytoconstituents such as flavonoids, phenols, and steroidal lactones are responsible for the antidepressant effect. The FST and TST are the most widely used behavioral tools for assessing antidepressant activity. The development of immobility when rodents are suspended by their tail during TST and when they are placed in an inescapable cylinder of water during FST reflects the cessation of their persistent escape-directed behavior [22]. Conventional drugs reliably decrease the duration of immobility in animals during these tests. This decrease in duration of immobility is considered to have a good predictive value in the evaluation of potential antidepressant agents [23]. In the present study, decrease in immobility time with petroleum ether extract is not significant when compared with control in both TST and FST. A dose of $100 \mathrm{mg} / \mathrm{kg}$ p.o. CMA extract showed potent antidepressant-like effect in both TST and FST as indicated by highest decrease in immobility period. The effect was comparable to standard drug.

\section{CONCLUSION}

In the present study, the preliminary phytochemical analysis revealed that the presence of carbohydrates, proteins, tannins, and flavonoids in hydroalcoholic fraction. Ethyl acetate fraction showed positive results toward flavonoids, alkaloids, proteins, and steroids. Petroleum ether fraction showed positive results toward lipids; CMA and CME showed decreased immobility in FST and TST indicating their antidepressant activity. Hydroalcoholic fraction of guggul showed antidepressant activity, which was comparable to standard drug, i.e., imipramine $(10 \mathrm{mg} / \mathrm{kg})$. As reported earlier, guggul contains many bioactive compounds and majority of these compounds are steroids and proteins that are responsible for the health benefits. The antidepressant activity of these extracts may be attributed to steroidal compounds. Therefore, further study can be explored to evaluate the mechanism of antidepressant activity of $\mathrm{CM}$ by measuring monoamines and neurotransmitter levels in the brain.

\section{ACKNOWLEDGMENTS}

The authors are grateful to the management of the Chebrolu Hanumaiah Institute of Pharmaceutical Sciences and Sri Padmavathi Mahila Visvavidyalayam, for extending their support and providing facilities to complete this work.

\section{REFERENCES}

1. Rang HP, Dale MM, Ritter JM. Pharmacology. $5^{\text {th }}$ ed. Edinburgh: Churchill Livingstone; 2006. p. 535.

2. Richard HA, Pamella CC, Richad F, Luigi CX, Michelle CA. Lippincott's Illustrated Reviews: Pharmacology. $4^{\text {th }}$ ed. Baltimore, MD: Lippincott Williams and Wilkins; 2012. p. 142.

3. Dhingra D, Sharma A. A review on antidepressant plants. Nat Prod Radiance 2005;5(2):144-52.

4. Satyavati GV. Guggulipid: A promising hypolipidaemic agent from gum Guggul (Commiphora wightii). Econ Med Plant Res 1991;5:47-82.

5. Satyavati GV, Dwarakanath C, Tripathi SN. Experimental studies on the hypocholesterolemic effect of Commiphora mukul. Engl. (Guggul). Indian J Med Res 1969;57(10):1950-62.

6. Chaudhary G. Pharmacological properties of Commiphora wightii - An overview. Int J Pharm Pharm Sci 2012;4(3):73-5.

7. Anurekha J, Gupta VB. Chemistry and pharmacological profile of Guggul - A review. Indian J Tradit Knowl 2006;5(4):478-83.

8. Saxena VK, Sharma RN. Constituents of the essential oil from Commiphora mukul Gum resin. J Med Arom Plant Sci 1998;20:55-6.

9. Shah R, Gulati V, Palombo EA. Pharmacological properties of guggulsterones, the major active components of gum guggul. Phytother Res 2012;26(11):1594-605.

10. Sharma B, Salunke R, Srivastava S, Majumder C, Roy P. Effects of guggulsterone isolated from Commiphora mukul in high fat diet induced diabetic rats. Food Chem Toxicol 2009;47(10):2631-9.

11. Siddiqui MZ. Guggul: An excellent herbal panacea. Asian J Pharm Health Sci 2011;1:35-39.

12. Singh BB, Mishra LC, Vinjamury SP, Aquilina N, Singh VJ, Shepard N. The effectiveness of Commiphora mukul for osteoarthritis of the knee: An outcomes study. Altern Ther Health Med 2003;9:74-9.

13. Sosa S, Della TA, Loggia R, Bombardelli E. Anti-inflammatory activity of Commiphora mukul extracts. Pharmacol Res 1993;27:89-90.

14. Harborne JB. Phytochemical Methods - A Guide to Modern Techniques of Plant Analysis. $2^{\text {nd }}$ ed. New York: Chapman and Hall; 1984. p. 1-10.

15. Kokate CK, Purohit AP, Gokhale SB. Pharmacognosy. $12^{\text {th }}$ ed. Pune, India: Nirali Publication; 1999. p. 156-8.

16. Steru L, Chermat R, Thierry B, Simon P. The tail suspension test: A new 
method for screening antidepressants in mice. Psychopharmacology (Berl) 1985;85(3):367-70.

17. Thierry B, Stéru L, Simon P, Porsolt RD. The tail suspension test: Ethical considerations. Psychopharmacology (Berl) 1986;90(2):284-5.

18. Porsolt RD, Bertin A, Jalfre M. Behavioral despair in mice: A primary screening test for antidepressants. Arch Int Pharmacodyn Ther 1977;229(2):327-36

19. Stahl SM. Essential Psychopharmacology: Neuroscientific Basis and Practical; Applications. Cambridge: Cambridge Univertsity Press; 1998. p. 395

20. Santhosh P, Venugopal R, Nilakash S, Kunjbihari S, Mangala L, Anti-depressant activity of methanolic extract of Passiflora foetida leaves in mice. Int J Pharm Pharm Sci 2011;3(1):112-5.

21. Sembulingam K, Sembulingam P, Namasivayam A. Effect of Ocimum sanctum Linn on noise induced changes in plasma corticosterone level. Indian J Physiol Pharmacol 1997;41(2):139-43.

22. Umadevi P, Murugan S, Jennifer S, Subakanmani S. Evaluation of antidepressant like activity of Cucurbita pepo seed extracts in rats. Int J Curr Pharm Res 2010;3(1):108-13.

23. Ishola IS, Chatterjee M, Tota S, Tadigopulla N, Adeyemi NO, Palit $\mathrm{G}$ et al Antidepressant and anxiolytic effects of amentoflavone isolated from Cnestis ferruginea in mice. Pharmacol Biochem Behav 2012;103:322-31. 